\title{
OS ASSENTAMENTOS FANTASMAS E A METAFÍSICA DA REFORMA AGRÁRIA: ANÁLISE DA RELAÇÃO ENTRE O INCRA NO OESTE PARAENSE, A EXTRAÇÃO ILEGAL DE MADEIRA E OS NÚMEROS DO II PNRA ${ }^{1}$
}

\author{
MAURICIO TORRES ${ }^{2}$ \\ Universidade Federal do Oeste do Pará
}

Resumo: Logo no início de 2007, terminado o primeiro mandato do presidente Lula, o Ministério do Desenvolvimento Agrário (MDA) apresenta vultosos números de famílias assentadas pela Superintendência do Incra ${ }^{\circ} 30$, no oeste paraense. Em pouco tempo, esses dados são desmascarados e questionados judicialmente, descortinando-se como, além da inflação de números para efeito de se anunciar o cumprimento do II Plano Nacional da Reforma Agrária, a criação de assentamentos foi pautada não pela demanda de famílias camponesas sem terra, mas pelo interesse criminoso do agronegócio da madeira. Tudo se passa em meio ao caos fundiário do oeste do Pará, em que a destinação de terras públicas ganha a alcunha de reforma agrária.

Palavras-chave: Reforma Agrária; Amazônia; Exploração Madeireira; Grilagem; Destinação de Terras Públicas.

THE GHOST SETTLEMENTS AND THE METAPHYSICAL AGRARIAN REFORM: AN ANALYSIS OF THE RELATION BETWEEN INCRA'S ACTIONS IN THE WEST OF THE STATE OF PARÁ, THE ILLEGAL EXTRACTION OF TIMBER, AND THE AGRARIAN REFORM NUMBERS OF THE SECOND PNRA

Abstract: At the beginning of 2007, after the end of President Lula's first administration, the Agrarian Reform Ministry (MDA) published a long list of the number of families settled by the Incra

\footnotetext{
${ }^{1}$ Plano Nacional de Reforma Agrária.

2 Maurício Torres é doutor em Geografia Humana pela Universidade de São Paulo e professor colaborador do Programa de Pós-Graduação em Recursos Naturais da Universidade Federal do Oeste do Pará. Contato: mautorre@gmail.com.
} 
Superintendency $n^{\circ} 30$ in the west of Pará. Very soon these figures were unmasked and questioned in the courts, and it was revealed that, along with the inflation of the numbers so that the government could claim that the second National Plan of Agrarian Reform had been fulfilled, the creation of the settlements had been driven, not by the demand of landless peasant families, but by the criminal interests of the timber companies. All this happened against the background of the land ownership chaos of the east of Pará, where the selling off of public land gained the epithet of agrarian reform.

\section{LOS ASENTAMIENTOS FANTASMA Y LA METAFÍSICA REFORMA AGRARIA: ANÁLISIS DE LA RELACIÓN ENTRE EL INCRA EN EL OESTE DE PARÁ, LA EXTRACCIÓN ILEGAL DE MADERA Y LAS CIFRAS DE LA REFORMA AGRARIA DEL II PNRA}

Resumen: Desde el principio de 2007, terminado el primer mandato del presidente Lula, el Ministerio de Desarrollo Agrario (MDA) presenta abultadas cifras de familias asentadas por la Superintendencia del Incra $n^{\circ} 30$, en el oeste de Pará. Em poco tiempo, esos datos son desenmascarados y cuestionados judicialmente y se destapa cómo, además de hincharlos números con el propósito de anunciar el cumplimiento del II Plan Nacional de Reforma Agraria, la creación de asentamientos fue pautada, no a petición de familias campesinas sin tierra, si no por los intereses criminales del agronegocio de la madera. Todo esto ocurre bajo el caos patrimonial del oeste de Pará, donde la adjudicación de tierras públicas recibe el apelativo de reforma agraria.

Palabras clave: Reforma Agraria; Amazonía; Explotación Maderera; Grilagem; Repartimiento de Tierras Públicas.

"Crescei e multiplicai-me, diz o latifúndio" (José Saramago. Levantados do chão).

\section{Introdução}

No final de janeiro de 2007, o Ministério do Desenvolvimento Agrário (MDA) divulgou o cumprimento de $95 \%$ da meta de famílias assentadas objetivadas no II Plano Nacional de Reforma Agrária (IIPNRA) para o primeiro mandato do governo Lula. Segundo o MDA, das 381.419 famílias assentadas, 49,22\% foram na Amazônia.

Passados quase quarenta anos desde os projetos de colonização da Amazônia empenhados pela ditadura militar, ainda se identificam os traços do que mostraram Ianni (1979), Martins (1984) e Oliveira (1997; 2005), entre outros: a reforma agrária do Brasil inteiro continua concentrada na Amazônia, ou melhor, a destinação de terras públicas na Amazônia continua sendo a válvula de escape política para a não reforma agrária. Permanece a necessidade de esvaziar a inquietação social causada pela concentração fundiária sem perturbar os interesses em jogo, de modo a não se permitir qualquer vislumbre de redistribuição da terra. Ou seja, a reforma agrária mantém intocada a "sagrada instituição" do latifúndio.

Porém, se na década de 1970 a "reforma agrária na Amazônia" tinha como 
preocupação o abastecimento de mão de obra para os "investidores na Amazônia" (IANNI, 1979; OLIVEIRA, 1997; 2005); a que aconteceu em 2005 e 2006, especialmente na Superintendência Regional do Instituto Nacional de Colonização e Reforma Agrária (Incra) de Santarém (SR30), região oeste do Pará, tinha no front outras preocupações, embora tampouco fosse a demanda dos camponeses sem terra. Os assentamentos criados prestaram à intenção de abastecer o lucrativo agronegócio da madeira com terras públicas não destinadas, que seriam transformadas em áreas com situação fundiária regular onde poderiam ser licenciados projetos para exploração madeireira aptos a auferirem preços algumas vezes maiores, por estarem revestidos - ainda que muito superficialmente - de um ralo verniz de legalidade. E, de quebra, o simulacro de reforma agrária corroborou a inflação fictícia dos números oficiais, servindo como propaganda eleitoreira de uma reforma agrária que não houve.

Este texto busca mostrar, por um lado, o processo e os mecanismos segundo os quais o Estado e grupos econômicos arquitetaram e manipularam políticas territoriais para revestir de legalidade e viabilizar o saque das florestas públicas na Amazônia. Por outra face, apresentamos o farsesco anúncio do enorme número de famílias assentadas e a factual negação da reforma agrária àqueles que há muito lutam pela terra de trabalho, em todo o país e nesta mesma região.

A área enfocada neste artigo é o oeste do Pará, nos limites onde o Incra atua por meio da SR30, uma extensão aproximada de 70 milhões de hectares (ver Mapa 1). Trata-se da mais nova superintendência regional do Incra, criada após o assassinato da missionária Dorothy Stang e enquanto promessa de ordenamento fundiário necessário para obras de infraestrutura, como o asfaltamento da BR-163. O processo de criação dos projetos de assentamento aqui tratados se concentrara em 2005 e 2006, mas o caso se desdobra até os dias atuais.

\section{A malha fundiária paraense: ilegalidade fundante}

A maioria das terras na área de atuação da SR30 pertence à União (TORRES, 2012). Isso se deve à promulgação do Decreto-Lei $n^{0} 1.164 / 1971$, que federalizou uma faixa de $200 \mathrm{~km}$ ao longo das rodovias federais existentes, em construção ou projetadas, e ao Polígono Desapropriado de Altamira, uma área de 6 milhões de hectares desapropriada pelo Decreto $n^{0}$ 68.443/1971 e destinada à implantação de programas de colonização e reforma agrária.

Se em Mato Grosso a tomada de grande parte das terras públicas, incluindo territórios indígenas, acabou por ser legitimada em tortuosos caminhos (MORENO, 1993; OLIVEIRA, 1997), no oeste do Pará, as impressionantes extensões de terras controladas por grileiros, ao menos até 2009 , ainda não haviam sido "esquentadas", 
não haviam adquirido qualquer tido de documentação legal ${ }^{3}$. Para muitos, isso não causava maiores problemas. Vendiam seus bois, sua soja, seu arroz ou qualquer outra coisa que plantada ou criada sem que, na prática, ninguém pergunte se a área onde foi produzida é documentada ou se é terra pública ilegalmente tomada. Até para obtenção de financiamentos o grileiro não encontra grandes empecilhos. Quando os bancos públicos endureciam um pouco, podiam-se obter recursos com a Cargill, por exemplo, que patrocinou na região de Santarém a derrubada de florestas primárias e o plantio de soja em áreas sem nenhuma documentação de propriedade, no mais claro incentivo à grilagem e ao crime ambiental (TORRES, s.d.).

A extração madeireira se diferenciava da agropecuária: o sistema de emissão de licenças de exploração e transporte do produto é um pouco mais seletivo em relação à sua origem, e a fiscalização ambiental era (ou ao menos entre 2004 e 2009 estava) ${ }^{4}$ relativamente presente no controle de estocagem e transporte de madeira. Portanto, para transportar e vender madeira havia que se ter a devida licença e, para tal, teoricamente seria necessária a documentação fundiária da área de extração.

Porém, a complacência de sucessivos governos com a grilagem decidiu que seria rigor excessivo exigir prova de propriedade da terra para se conceder a autorização para extração madeireira. Assim foi até 2004. O saque das florestas públicas em benefício de uma meia dúzia de madeireiros era oficialmente licenciado.

A partir de 2004, o Ibama começou a se posicionar no sentido de não mais abrir mão do título fundiário, ou de outro documento lídimo, para fins de emissão de licença de exploração madeireira, não mais bastaria a apresentação das "Certidões de Posse", sempre, emitidas pelo Incra e muitas vezes em favor do grileiro que pagasse mais, como foi bastante aclarado por ocasião da Operação Faroeste, da Polícia Federal, no final de $2004^{5}$. E, neste momento de particular cerceamento da ilegal atividade madeireira, foi promulgada uma medida conjunta do Incra e do

\footnotetext{
${ }^{3}$ A grilagem adotou outros rumos após ser consideravelmente facilitado pela promulgação da Medida Provisória 458/2009, que dispôs "sobre a regularização fundiária das ocupações incidentes em terras situadas em áreas da União, no âmbito da Amazônia Legal", sancionada na forma da Lei Ordinária $\mathrm{n}^{\mathrm{o}}$ 11.952/2009 pelo presidente Lula e que deu origem ao Programa Terra Legal.

${ }^{4}$ A região conheceu dois momentos distintos e efetivos em que - ainda que com recursos irrisórios frente à necessidade - houve controle na fiscalização de extração ilegal de madeira. Um deles iniciou-se em 2004, com a gerência do Ibama de Santarém sob o comando de Paulo Mayer e uma efetiva ação do escritório do Ibama de Itaituba, sob o comando de José Kalrson Correia da Silva. (TORRES, 2005, p. 411s. Outro período de pressão sobre os madeireiros foi de maio de 2007 a novembro de 2008, quando Daniel Cohenca ocupou a gerência do Ibama em Santarém. A incisiva ação de Cohenca enfureceu madeireiros (e os políticos com campanhas eleitorais financiadas por eles) a ponto de ter sido exonerado do cargo após uma verdadeira tramoia de acusações. Depois de ter sido inocentado de todas as acusações, Cohenca veio a público e denunciou os reais interesses encobertos pelas acusações sobre ele e por sua exoneração. Sobre o caso, veja-se Daniel Cohenca, ex-gerente do Ibama de Santarém, diz que PT usou órgão para vencer eleições municipais no Oeste do Pará e Nota de esclarecimento (COHENCA, Daniel).

${ }^{5}$ Sobre a emissão de Certidões de Posse para aprovação de PMF, veja-se Torres (2005) e, também, a ampla divulgação a respeito da Operação Faroeste, deflagrada pela Polícia Federal em dezembro de 2004, que levou à prisão do então superintendente do Incra no Pará e de vários outros grileiros e servidores públicos.
} 
MDA que dificultava bastante o caminho que a grilagem trilhava, a Portaria Incra/MDA n 10, de 10 de dezembro de 2004.

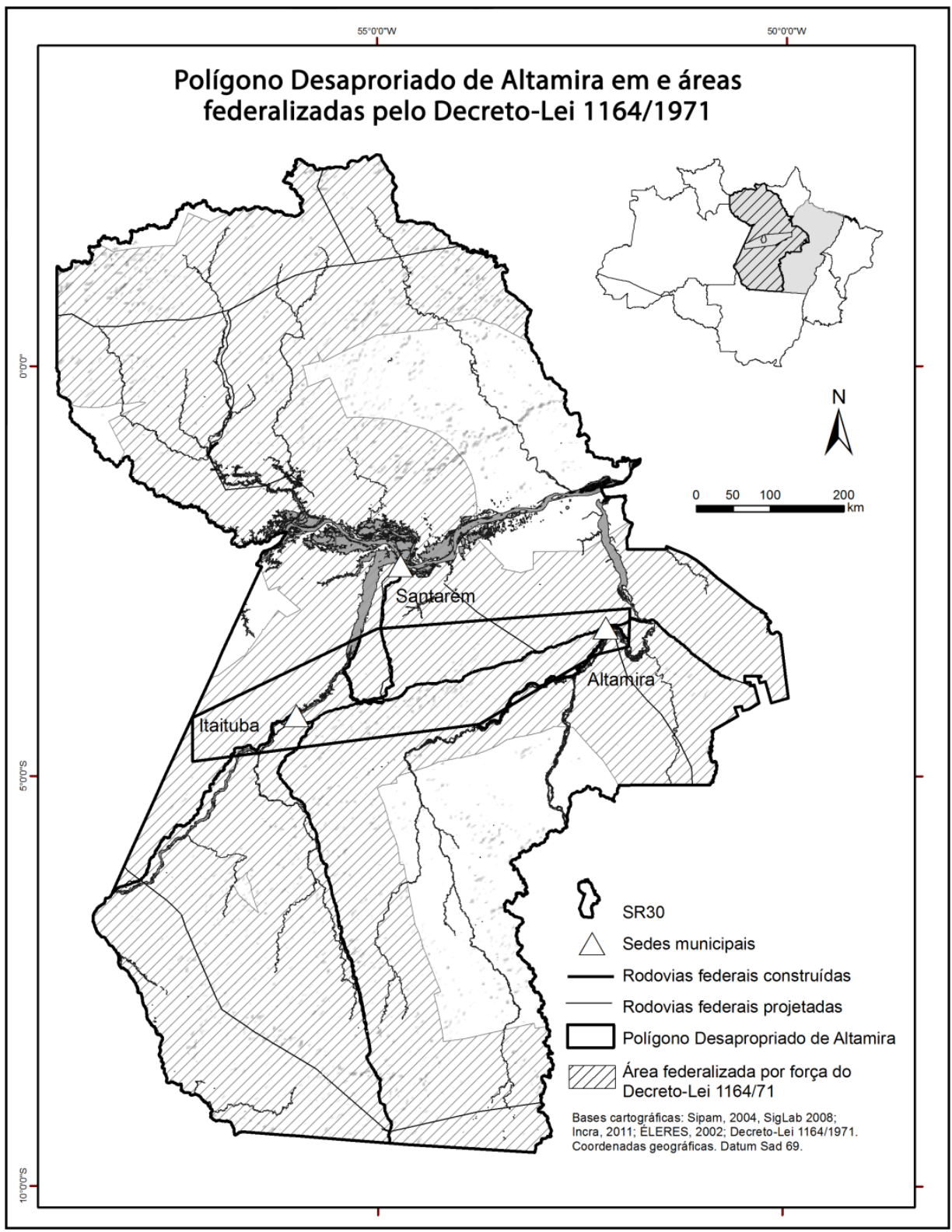

Mapa 1: Polígono desapropriado em Altamira em áreas federalizadas pelo Decreto-Lei 1164/1971. 
O duro golpe desferido pela portaria na grilagem vinha esclarecido no artigo $7^{\circ}$ : "Os documentos cadastrais ou outros expedidos pelo Incra, referentes a imóveis localizados em terras públicas federais não fazem prova de propriedade, posse de boa-fé ou de direitos a elas relativos" (MDA; INCRA, 2004), o que foi complementado com a proibição de emissão de novos Certificados de Cadastro de Imóveis Rurais (CCIR) em terras da União.

Para os madeireiros foi um golpe devastador, pois dependiam da aprovação dos projetos de extração da madeira, que depende da regularidade fundiária. A Portaria, inclusive, foi claríssima em seu artigo $4^{\circ}$ em vedar qualquer possibilidade de novamente se expedirem as malfadadas "Certidões de Posse" para aprovação de PMF.

No mesmo dia 10 de dezembro de 2004, o diretor de Florestas do Ibama, Antônio Carlos Hummel, assina o Memorando $n^{\circ}$ 619, recomendando - além da não emissão de novas licenças - o cancelamento de todos os PMF que tivessem sido aprovados em terras não tituladas. O então gerente do Ibama em Santarém-PA, Paulo Maier, foi o único em toda a Amazônia a cumprir a recomendação, enfrentando por conta disso uma enorme pressão de madeireiros, grileiros e até de setores do alto escalão do Ministério do Meio Ambiente (MMA), como o então diretor do Programa Nacional de Florestas, Tasso Rezende de Azevedo ${ }^{6}$. Queixavam-se, biliosos, de que o setor mergulharia em uma terrível crise por conta do posicionamento do Ibama. Ironicamente, a própria queixa era uma autodeclaração de que todo o setor atuava na ilegalidade, roubando madeira de terras públicas.

Ainda que o setor operasse mergulhado na ilegalidade, eram comuns as falas de autoridades do Governo Federal demonstrando preocupação com a sustentação dos madeireiros (SOUZA, 2005; TORRES, 2012). A "solução final" para perenizar o saque das florestas públicas com sua entrega definitiva aos madeireiros estava a caminho: a Lei ( $\mathrm{n}^{\circ}$ 11.284/06) de Gestão de Florestas Públicas (TORRES, 2008). Porém, como todos sabiam que ainda se demoraria anos para colocá-la em prática, o milionário e ilegal agronegócio da madeira no oeste do Pará começava o ano de 2005 em xeque.

Entretanto, nos bastidores, costurava-se, sob o manto da reforma agrária, um novo meio para garantir ao agronegócio maneira de seguir se apoderando das florestas públicas.

\footnotetext{
6 “A recomendação de Antônio Carlos Hummel é tecnicamente correta e pretendia justamente legalizar a situação dos planos de manejo. Apesar disso, Tasso de Azevedo, então, diretor do Serviço Florestal Brasileiro, considera que seria uma 'insanidade' suspender unilateralmente todos os planos na Amazônia em virtude da redução drástica no volume de madeira disponível. 'Se a gente fosse muito irresponsável, se quiséssemos causar o caos e colocar todo mundo para desmatar a Amazônia, era isso que a gente tinha que fazer'. Azevedo também considera a decisão de Maier 'precipitada'. 'A rigor, ele não precisava ter suspendido. Só precisava suspender quando entregassem a documentação no Incra, até 31 de janeiro, e se os CCIRs fossem inibidos"” (SOUZA, 2005).
} 


\section{"Um uso criminoso da reforma agrária"}

A partir de 2005, com a inauguração da SR30, até 2006, ocorre uma colossal criação de assentamentos na região. Pedro Aquino de Santana, o superintendente, alardeia ser conhecido por Lula pela alcunha de "o homem da reforma agrária".

Simultaneamente à produção em massa de assentamentos, os madeireiros voltam à cena na posição de grandes paladinos da reforma agrária. A imprensa local registra curiosas declarações: "presidente do Sindicato de Indústrias Madeireiras do oeste do Pará diz que o setor madeireiro é o maior interessado na implantação dos PDS [Projeto de Desenvolvimento Sustentável, modalidade de assentamento que analisaremos adiante]"; "madeireiros concordam em abrir mão do direito às suas posses para a criação de PDS"; "madeireiros disponibilizam 100 mil hectares para a criação de PDS"; "segundo o Simaspa [Sindicato das Indústrias Madeireiras do Oeste do Pará], as indústrias madeireiras já passaram ao Incra as coordenadas para a implantação dos PDS" (JORNAL DE SANTARÉM E BAIXO AMAZONAS, 2005, p. 7).

Em 2005, a estranha predisposição do madeireiro à reforma agrária era registrada por um jornalista local declaradamente ligado ao setor:

o setor madeireiro da região é quem mais tem interesse e defende a implantação dos PDS. Tremonte [presidente de um sindicato madeireiro] enviou à reportagem cópia de mais de 10 documentos enviados para senadores, ministros, deputados e para diretores do Incra todos pedindo a imediata instalação dos projetos [de assentamentos] e passando as coordenadas de áreas onde poderiam ser assentadas as famílias na nova modalidade de assentamento.

(...) os próprios empresários do setor fizeram a proposta de criar os PDS em áreas que atualmente são ocupadas por madeireiros. "São áreas sob posse mansa e pacífica", diz Tremonte, afirmando que o setor propôs ao Incra "doar" mais de 500 mil hectares para a instalação de projetos na região, tendo inclusive enviado as coordenadas de uma área de 30 mil hectares para implantação imediata dos PDS (LEAL, 2005, 7. Grifos nossos).

Situação emblemática: madeireiros ofereciam "doar mais de 500 mil hectares" de terras do Incra ao próprio Incra e chegavam a enviar as coordenadas para a criação do PDS. E isso é algo que extrapola a superintendência de Santarém e contava com a conivência e o comprometimento de, ao menos, um diretor nacional, como registra a matéria abaixo:

No dia 08 de maio [de 2005], diversos empresários do setor madeireiro na região oeste do Pará se reuniram, em Itaituba, com 
o então superintendente do Incra de Belém, Inocêncio Gasparim, na época responsável pelo Incra do oeste paraense. Naquele mesmo dia, detentores de terra na região concordaram em abrir mão do direito à posse para criação dos PDS. As áreas apresentadas pelos madeireiros são bem localizadas, com estradas e com cobertura florestal mantida, o que permite perfeitamente a implantação dos PDS.

No mês de outubro, várias reuniões foram feitas em Santarém e em Itaituba para definir as regras dos projetos, uma vez que já haviam sido disponibilizados cerca de 100 mil hectares para criação de PDS naquele mês. O diretor nacional do Incra, Raimundo Lima, em entrevista ao JSBA [Jornal de Santarém e Baixo Amazonas] disse que o órgão estava fazendo a parceria com o setor florestal, que 15 mil famílias seriam assentadas nos PDS e que até o final de junho de 2006 estariam liberados os projetos de manejo que permitiriam a exploração da reserva legal de cada PDS.

Empresários que participaram das negociações desde o início disseram à reportagem que as declarações de Pedro Aquino [então, superintendente da SR30] coincidem com o fim do prazo para a criação dos PDS e com o fato de nenhum projeto ter sido efetivamente implantado até o momento. "E o Incra não tem recursos, pois o Aquino pediu que os próprios empresários bancassem os custos. (...)", garante um empresário da região de Novo Progresso (JORNAL DE SANTARÉM E BAIXO AMAZONAS, 2005. Grifos nossos).

Por trás de tamanho altruísmo dos madeireiros, ocultava-se um pacto que o geógrafo Ariovaldo Umbelino de Oliveira qualificou como "um uso criminoso da reforma agrária" (GUERREIRO, 2007, p. 36): seriam usados assentamentos como área regularizada em termos fundiários para a extração de madeira. $\mathrm{O}$ Incra usaria a reforma agrária para um fim diametralmente oposto: garantir a apropriação e a concentração dos recursos nas mãos do madeireiro, mesmo que isso viesse em prejuízo de camponeses sem-terra e povos da floresta, como resumiu o Inquérito Civil Público (ICP) que investigou esse processo:

Verificou-se que tais projetos [de assentamentos] não atendem a uma autêntica demanda de potenciais clientes da reforma agrária. São, antes, resultado da pressão do setor madeireiro junto às esferas governamentais, que vislumbram nos assentamentos um estoque de matéria-prima cujo manejo é objeto de um licenciamento mais rápido, devido ao valor social que seu manejo apresentaria, em tese (ICP $\mathrm{n}^{\mathrm{o}}$ 1.23.002.000185/200776/PRM/STM/MPF, p. 5). 


\section{"Olha, os assentamentos podem resolver o problema do setor madeireiro lá na região": o assentamento de reforma agrária como forma de apropriação das madeireiras}

Caem os panos e os bastidores do esquema são explicados pelo então diretor nacional de Programas do Incra, Raimundo Lima, em reunião com os servidores da SR30. Na conversa gravada pelos participantes e transcrita abaixo, Lima conta sobre uma reunião, em novembro de 2004, envolvendo madeireiros e o primeiro escalão do Incra e do MMA, onde tudo fora tramado:

No momento daquela reunião foi provada a inviabilidade de a Lei de Gestão de Florestas Públicas resolver de imediato o problema dos madeireiros e foi efetuada uma sugestão. Primeiro: o hoje diretor geral do Serviço Florestal Brasileiro, o Tasso [Rezende de Azevedo] (...) e também o dr. Paulo Capobianco, que hoje é secretário-geral do Ministério [do Meio Ambiente] e na época era secretário de Biodiversidade, fizeram uma sugestão: "quantos assentamentos o Incra tem lá na região?” O superintendente respondeu e aí eles disseram: "Olha, os assentamentos podem resolver o problema do setor madeireiro lá na região". Aí, os madeireiros disseram: "Olha, mas nesses assentamentos que tem lá no Pará não existe mais madeira, não vai cobrir as nossas necessidades, não vai resolver o nosso problema... Mas o Incra vai criar assentamentos lá?"(...) Aí, o Rolf [Hackbart, então, presidente do Incra] já anunciou a criação da nova superintendência. E o Incra cria assentamentos lá na região, em terras públicas, e esses assentamentos serão as áreas que vão ofertar legalmente madeira para o setor madeireiro. (Raimundo Lima em reunião com os servidores da SR30, com a presença de Nilton Bezerra Guedes, diretor nacional de Obtenção e Implantação do Incra, e Pedro Aquino de Santana, superintendente da SR30; em 20 set. 2007. Registro de áudio, arquivo do autor).

A apropriação ilegítima dos recursos florestais pelos madeireiros encontra, então, a partir da reforma agrária, meio para parecer legal. Além de anteverem que isso poderia gerar o controle de imensas áreas com situação fundiária apta ao licenciamento da exploração madeireira, sabiam ainda que o controle dessas terras dentro de assentamentos se daria por meio da dependência dos assentados em relação a eles e, então, Incra e madeireiros reinventam mecanismos de submissão dos assentados: o endividamento compulsório. 
Os custos de infraestrutura, como os de estrada, demarcação topográfica, transporte e construção de barracões comunitários, deveriam ser de responsabilidade do Incra, e não de madeireiros. A falta de recursos financeiros e de capacidade técnica instalada no órgão em implantar o assentamento - e a própria indução para que os assentados recorram aos madeireiros - levam ao endividamento compulsório dos assentados. O pagamento da dívida, evidentemente, é a madeira, um recurso que, caso fosse apropriado por seu legítimo dono, o assentado, poderia ser uma contribuição decisiva no sucesso da instalação dessas famílias na terra (GREENPEACE, 2007, p. 22).

Chama a atenção que, quando reclamam por assentamentos, os madeireiros falam, específica e somente, da modalidade de PDS (Projeto de Desenvolvimento Sustentável), apesar do Incra ter outras modalidades. Isso porque anteviram nas peculiaridades desse tipo de assentamento o viés de um aprimoramento dos mecanismos de controle ilegal da floresta.

$\mathrm{O}$ formato do PDS, que a princípio apresenta características interessantes e propícias à Amazônia, acabou por atender a fins contrários à sua intenção, por isso, importa entender os pressupostos que levaram à formulação teórica desta modalidade de assentamento e as especificidades que permitiram aos madeireiros os controlarem.

Em 1999, a Portaria $n^{\circ} 88$ do então Ministério Extraordinário da Política Fundiária proibia o Incra de promover a instalação de assentamentos da reforma agrária em áreas com cobertura de floresta primária. Esse posicionamento, entretanto, obstaculizou o atendimento às comunidades tradicionais que habitam as florestas e que, por explorarem-na de modo extrativista, mantinham sua área majoritariamente composta de florestas primárias.

Como solução para isso, cria-se, em 1999, a modalidade de Projeto de Desenvolvimento Sustentável, que considerava "que as florestas brasileiras demandam um programa de reforma agrária que respeite as formas tradicionais de ocupação e produção de assentamento voltado especificamente à população que já ocupava as áreas de floresta primária" (INCRA, 1999).

A instituição da modalidade de PDS veio a flexibilizar - em favor das comunidades tradicionais - a proibição de se criar assentamentos em área de floresta. Porém, sua aplicação efetiva inverteu completamente essa vocação original. Foi possível constatar áreas imensas de assentamentos criados em locais absolutamente inapropriados para esse fim, mas com altíssimos interesses para as madeireiras (TORRES, 2012).

Criaram-se assentamentos como os PDS Renascer II, Liberdade I, Anjo da Guarda, Santa Rita, Santa Luzia, Ademir Federicci e dezenas de outros em áreas sem condições logísticas, sem avaliação dos solos, sem considerar relevo, tipo de vegetação, enfim, à revelia de qualquer critério técnico, mas com conhecido 
potencial madeireiro.

O protocolo para implantação de assentamentos prevê que sejam criados a partir da demanda de organizações populares. Porém, na prática instituída na SR30 muitas associações não surgiram das bases, de baixo para cima, mas de forma inversa. Comumente, foi o madeireiro o sujeito da iniciativa de criação da "associação comunitária". Primeiro ele escolhia e bancava um presidente que pudesse ser controlado. Esse presidente era garantido - via madeireiro - dentro do Incra e, assim, ficava fortalecido também diante dos assentados, acabando por ter mais autoridade para anular qualquer reação do grupo ao completo subjugo frente ao madeireiro, mesmo porque "os integrantes das associações de assentados, por sua vez, são cadastrados aleatoriamente, em locais muitas vezes distantes dos assentamentos, não configurando um grupo coeso e organizado"(GREENPEACE, 2007, p. 10).

A gestão centralizada do PDS e de sua reserva legal coletiva por uma associação e a imensa área de assentamentos criada na floresta potencializavam o esquema madeireiro.

\section{Madeireiro, "cliente da reforma agrária"}

Nessa "reforma agrária" voltada à voracidade dos madeireiros, o Incra ignorou a incompatibilidade entre os interesses dos madeireiros e dos camponeses sem terra. Para os primeiros, era necessário que os assentamentos fossem implantados em áreas com estoques ainda intocados de madeiras nobres, ou seja, nas distantes florestas primárias ainda não saqueadas. Porém, justamente essa condição eliminava chance de famílias camponesas se instalarem no local.

Basta sobrepor o traçado desses assentamentos aos dados de desmatamento para notar o lado para o qual pendeu o Incra. Os PDS foram criados em distantes áreas inabitadas e, justamente por serem de muito difícil acesso, cobertas por florestas virgens, como mostra o Mapa 2. Isso atendia a exigência dos madeireiros, como depôs Luís Carlos Tremonte, presidente do sindicato madeireiro Simaspa, indicando também a participação do primeiro escalão do Governo Federal no esquema:

Quero deixar bem claro: eu defendo a criação de novos PDSs. Tenho o documento que vou passar para os senhores aqui. De novos PDSs. Por quê? Os assentamentos que existem hoje não têm mais madeira, a realidade é essa. (...) Então, não adianta... Por que provavelmente eu estou falando isso? Porque, no dia 3 de fevereiro [de 2005], numa outra reunião, no Ministério do Meio Ambiente, sem a presença da Marina Silva, porém com a presença do Presidente do Ibama, do Presidente do Incra e todo o seu estafe, o que eles colocaram para nós para safra de 2005? Ou seja, nós estivemos, em agosto, implorando pela safra de 2004, não conseguimos. E o que sobrou para a safra 2005? Os 
projetos de assentamento e que eu, na oportunidade - vocês podem levantar no Ministério do Meio Ambiente -, no dia 3 de fevereiro, falei para todos: "Isso é utopia, porque os assentamentos não têm mais madeira". Quando eu me refiro à madeira, eu digo madeira comercial, não significa que está devastado. (Depoimento de Luiz Carlos Tremonte à CPI da Biopirataria, nº 1136/05. Brasília, 11 ago. 2005. Grifos nossos)

Tremonte parece ter sido ouvido. Partindo de Santarém, por exemplo, é possível viajar centenas de quilômetros atravessando áreas desmatadas por gado, arroz e soja. Nesses locais não foram criados assentamentos ${ }^{7}$. São latifúndios onde, muitas vezes, unem-se crime ambiental, trabalho escravo e grilagem de terras públicas, aliás, terras do Incra que foram federalizadas para a reforma agrária (ROCHA, 2005; ALMEIDA, 1988). A retomada dessas terras e sua destinação à reforma agrária é das mais evidentes- e também das mais negligenciadas - obrigações do Incra. São áreas com melhores condições de infraestrutura e logística, nas quais a criação de assentamentos, além de viável, não traria dano ambiental e ainda poderia gerar alguma recuperação, como a das matas ciliares, por exemplo.

O problema é que isso não atenderia ao setor madeireiro. Em 2005 e 2006, não há um único assentamento no oeste do Pará resultado da retomada da posse de terras griladas e desmatadas. A sobreposição da base cartográfica do Incra a imagens de satélites mostra como os assentamentos contornam o pasto do grileiro com preciso cuidado e ficam limitados à área coberta por florestas onde o grileiro não desmatou (TORRES, 2012).

Os madeireiros determinaram onde deveriam ser implantados os assentamentos. Caso exemplar é o processo em que a madeireira Precious Woods Belém Ltda. manifesta interesse pela criação de um assentamento e indica coordenadas geográficas para tal. Na área indicada pela madeireira holandesa e em seu entorno, foi criado o gigantesco PDS Liberdade I, com 450 mil hectares e capacidade para 3.500 famílias. Porém, o que acontece é um perfeito caso de assentamento fantasma. A área é ocupada por florestas primárias e não há nenhuma das famílias "assentadas" em seu interior, apenas a madeireira em plena atividade.

A madeireira manda, escolhe e determina, de acordo com sua conveniência, o local do assentamento, o modo de uso da terra e o número de famílias que devem ser assentadas. Ao Incra resta acatar as determinações e providenciar o necessário à sua efetivação.

\footnotetext{
${ }^{7}$ Não estamos considerando nessa análise os Projetos de Assentamentos Agro-Extrativista (PAE), uma vez que, na região, cumpriram a função de regularização fundiária em territórios tradicionalmente ocupados.
} 


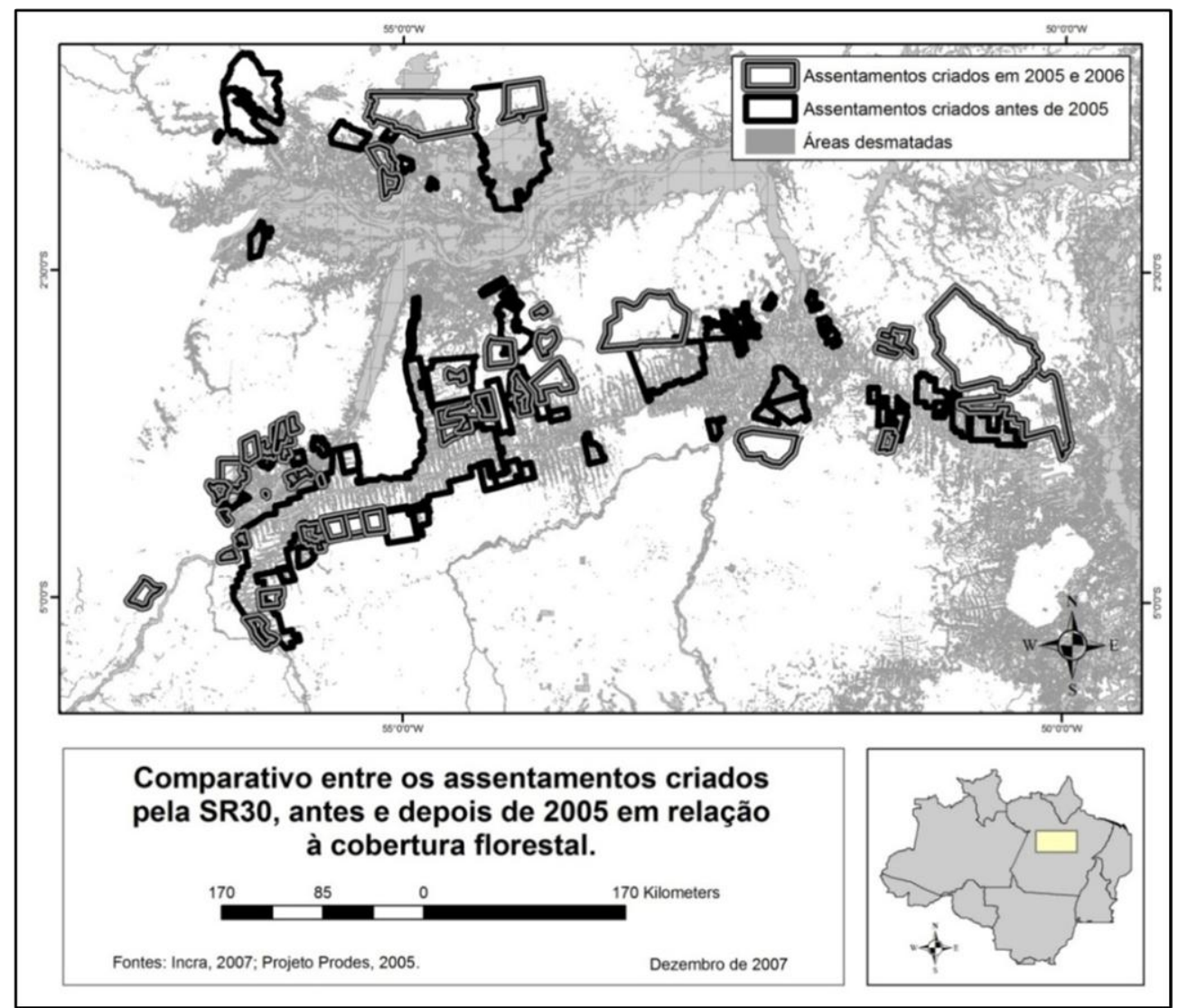

Mapa 2: Comparativo entre os assentamentos criados pela SR30, antes e depois de 2005, em relação à cobertura florestal.

Fontes: Incra, 2007; Projeto Prodes, 2005.

\section{Metas e atropelos}

A desenfreada criação de assentamentos na floresta, além de contentar o madeireiro (esse aliado político e consequente financiador de campanha), também alimentou a burlesca farsa dos números de assentados pelo II Plano Nacional de Reforma Agrária do governo Lula.

O programa Fantástico, levado ao ar pela TV Globo em 19 de agosto de 2007 (TORRES, 2007a; 2007b e GREENPEACE, 2007) revelou que dezenas de milhares de famílias assentadas pela SR30, de fato, simplesmente não existiam. Eram "de mentira". Os assentamentos foram criados apenas no papel e dezenas de milhares de famílias foram homologadas em assentamentos que factualmente não existem, ou existem em lugares dos quais nunca ouviram falar e a dias de viagem de onde 
vivem. Muitas delas sequer sabem que constam como assentadas nos cadastros do Incra. Enfim, a terra não foi entregue às famílias que o Incra computou como assentadas. No interior dos assentamentos só se encontra uma voraz exploração das madeireiras e comunidades que a estas se submetem, comumente, em meio a sérios conflitos.

Nos processos de criação dos assentamentos, as normativas que regulamentam a matéria foram gritantemente ignoradas. Para o Procurador da República Felipe Braga, esse atropelo cumpriu a função de suprir a inatividade de outras superintendências. "Toda a estrutura da superintendência foi usada para gerar números artificiais de assentados em 2005 e 2006. O Incra assumiu certas metas no II Plano Nacional de Reforma Agrária que não vinham sendo atendidas por outras superintendências Brasil afora. (...) a cada viagem a Brasília, o superintendente trazia um novo aumento das metas" (comunicação pessoal, out. 2007).

Os próprios servidores da SR30, por meio de sua associação, a Assera (Associação dos Servidores da Reforma Agrária), afirmam que

as metas da SR30 foram crescendo durante o ano de 2006. Inicialmente eram 15 mil famílias, depois aumentaram para 20 mil e pouco depois para 30 mil. Na última semana do ano, chegaram a 36 mil. O objetivo sempre foi muito claro, era simplesmente para o governo dizer para a sociedade que tinha cumprido as metas do IIPNRA (ASSERA, comunicação pessoal, nov. 2007).

Essa "fabricação em massa" de assentamentos se deu em detrimento de toda e qualquer normativa que regulamentasse os processos de criação dos projetos e da triagem de candidatos. Para Braga, "o nível de irregularidades nos processos de criação de assentamentos é assustador e a pressão sobre técnicos e servidores para que atropelassem todas as normas internas da autarquia foi tremenda" (comunicação pessoal, out. 2007).

Os servidores da SR30 veem um quadro generalizado de caos:

O mais absurdo de tudo é que assentamentos foram criados sem nenhuma das peças técnicas obrigatórias. Há processo em que há um ofício pedindo a formalização do próprio processo e logo em seguida a portaria de criação. O trâmite normal do Incra envolve desde a vistoria da área, consecução dos laudos de vistoria, mapas temáticos, pareceres de chefes, pareceres jurídicos, parecer de cartografia para evitar sobreposição de áreas de reservas ambientais, de terras indígenas, de unidades de conservação. A direção do Incra sabia disso e fingia que não sabia. Antes de os técnicos entregarem qualquer coisa dizendo se o assentamento era viável ou não, já existia uma portaria dizendo: "criado" (ASSERA, comunicação pessoal, nov. 2007). 
A direção nacional tinha a mais plena ciência do que se passava na regional do Incra em Santarém. Em junho último, um relatório interno do próprio Incra sobre a situação da SR30 documenta um quadro surreal. Entre outras muitas irregularidades, registrou-se que, no lugar dos diversos estudos de viabilidade e procedimentos formais, encontrou-se processos de criação de assentamentos "constituídos por apenas três páginas (memorando de formalização do processo, folha escrita 'confere' e cópia da Portaria de criação do projeto), numa clara demonstração de desconsideração dos normativos internos" (INCRA, 2007).

\section{Os números da reforma agrária}

Até o dia 31 de dezembro de 2004, em toda a história do oeste do Pará, foram assentadas 21.524 famílias $^{8}$. E isso contando toda a megalopsiquia do projeto de colonização da Amazônia empreendido durante a ditadura militar - com verbas faraônicas - e as ações posteriores do Incra. Os passivos social e ambiental gerados por esse processo são incomensuráveis e, até hoje, representam uma situação não resolvida.

Porém, perto da febre de números da reforma agrária do governo- aliada à incondicional subserviência aos madeireiros -, os devaneios de grandeza dos militares ficaram reduzidos a amadorismos. Em apenas dois anos, foram "assentadas" 51.700 famílias. Só em 2006, homologou-se 33.700 famílias, mais do que em toda a história do oeste paraense até 2004.

Um comparativo entre o número de famílias assentadas historicamente nas regiões Sul e Sudeste, onde há enormes demandas, e o número de assentadas apenas nos anos de 2005 e 2006 na área de abrangência da SR30 dá a proporção do feito.

Como verificamos nos Gráficos 1 e 2 e na Tabela 1, apenas em 2006 a SR30 homologou um número de famílias maior que o de assentadas na história da Região Sul e praticamente igual ao da Região Sudeste em mais de cem anos.

A grandiosidade dos números e a velocidade dos feitos é, por si, um indicativo da inverossimilhança desta "reforma agrária" na Amazônia. Com o pequeno contingente da recém-criada superintendência, não houve, inclusive, qualquer seleção quanto à adequação das famílias beneficiárias, como mostrou Guerreiro (2007).

Oficialmente, o Incra nacional não assumiu até hoje o público e notório esquema dos assentamentos fictícios, criados para madeireiras. Inicialmente, limitou-se a soltar, de quando em quando, uma ou outra nota oficial garantindo que nada acontecia, sem responder jamais às graves acusações. Porém, dentro da SR30 a tática foi outra: houve uma tentativa de banalizar o feito. Tentou-se colocar o

\footnotetext{
${ }^{8}$ Para efeito, nesta análise, como oeste do Pará entenda-se a área de atuação da SR30.
} 
esquema como "política pública de reforma agrária", como se a instalação da madeireira fosse a forma de viabilizar o assentamento.

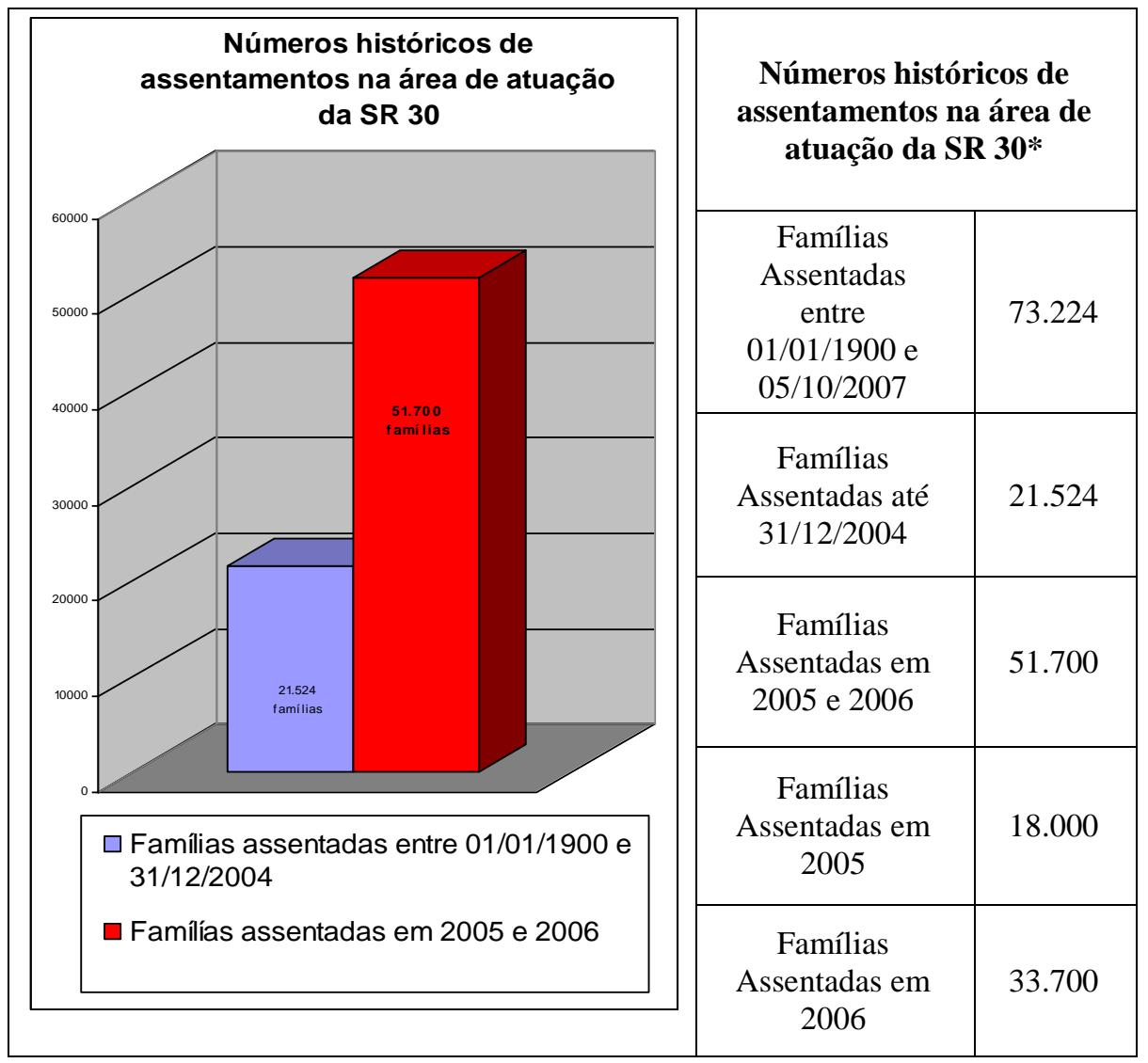

Gráfico 1: Comparativo de famílias assentadas na área da SR30 por período.

*A planilha Projetos de Reforma Agrária Conforme Fases de Implementação retrata os dados consolidados no dia 04/10/2007. Famílias homologadas em 2006, em assentamentos criados em 2000, por exemplo, constam nos dados de assentados até 2000. Nas planilhas Relação de Beneficiários Assentados dos anos de: 2005 e 2006 temos a certeza de que foram homologadas (ou assentadas, como o Incra prefere) 18.000 e 33.700 famílias pela SR30 em 2005 e 2006, respectivamente. O que confrontaria os dados da planilha Projetos de Reforma Agrária Conforme Fases de Implementação, que atribui à SR30 23.065 assentados em 2005 e 21.265 assentados em 2006. A diferença se explica, pois, em 04/10/2007, data da elaboração dessa planilha, computou-se como dados de 2005 famílias assentadas em 2006 nos assentamentos criados em 2005, dessa forma, famílias homologadas em 2005 e 2006 em assentamentos criados em anos anteriores a 2005. Constam nessa tabela dados de assentados no ano de criação dos assentamentos e não no de homologação das famílias.

Fonte: INCRA - Sipra; Diretoria de Obtenção de Terras e Implantação de Projetos de Assentamento DT. Projetos de reforma agrária Conforme Fases de Implementação: Período da Criação do Projeto: 01/01/1900 até 05/10/2007. 04 out. 2007. Disponível em: <http://www.incra.gov.br/arquivos/0277102527.pdf>. Acessado em dez. 2007. 
INCRA - Sipra; Diretoria de Obtenção de Terras e Implantação de Projetos de Assentamento - DT. Relação de beneficiários assentados no ano de: 2005. Acessado em dez. 2007. Disponível em: <http://www.incra.gov.br/arquivos/0277001571.pdf>.

INCRA - Sipra; Diretoria de Obtenção de Terras e Implantação de Projetos de Assentamento - DT. Relação de beneficiários assentados no ano de: 2006. Acessado em dez. 2007. Disponível em: <http://www.incra.gov.br/arquivos/0277001571.pdf〉.

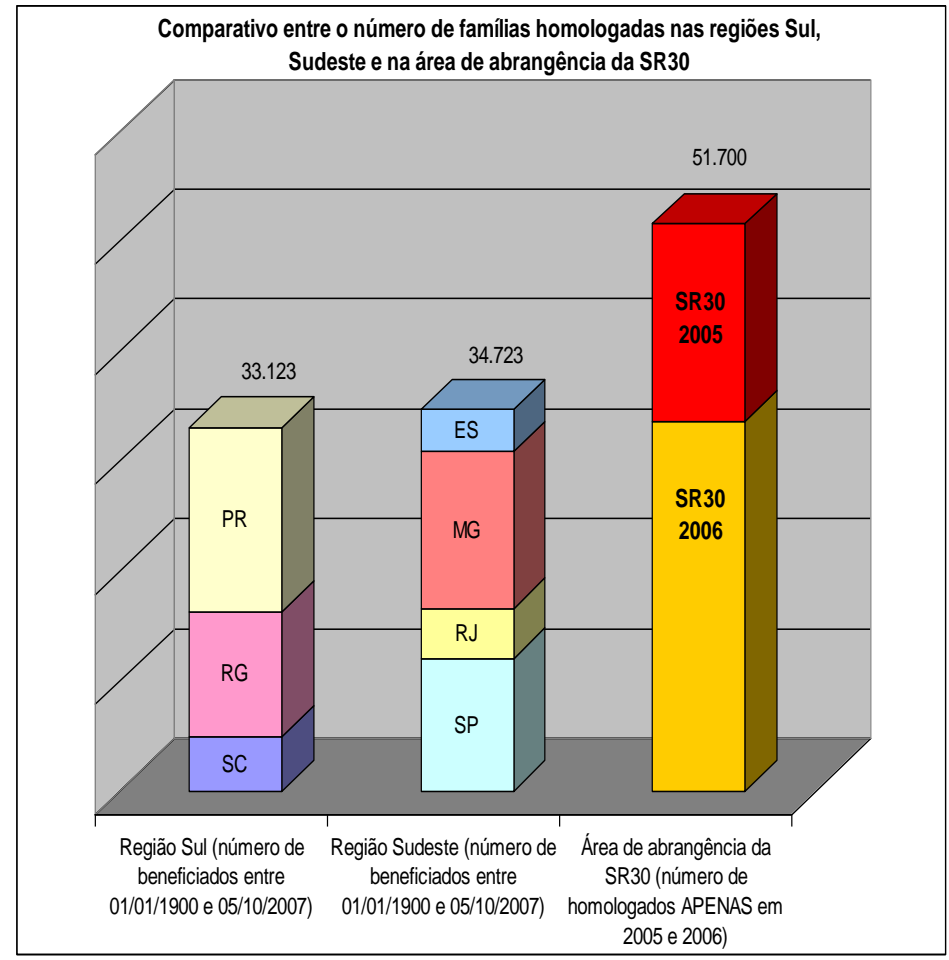

Gráfico 1: Comparativo de famílias assentadas por estados e regiões. Fonte: Id. Ibid.

\begin{tabular}{c|c|c}
\hline \multicolumn{3}{c}{$\begin{array}{c}\text { Comparativo entre o número de famílias homologadas historicamente } \\
\text { nas regiões Sul e Sudeste, e nos anos de 2005 e 2006 na área de } \\
\text { abrangência da SR30 }\end{array}$} \\
\hline \multicolumn{3}{c}{$\begin{array}{c}\text { Região Sul } \\
\text { Número de beneficiados homologados entre } \\
\text { 01/01/1900 e 05/10/2007 }\end{array}$} \\
\hline SR 10 & Santa Catarina & 4.988 \\
\hline SR 11 & Rio Grande do Sul & 11.393 \\
\hline SR 09 & Paraná & 16.742 \\
\hline
\end{tabular}




\begin{tabular}{|c|c|c|}
\hline \multicolumn{2}{|r|}{ Total } & 33.123 \\
\hline \multicolumn{3}{|c|}{$\begin{array}{c}\text { Região Sudeste } \\
\text { Número de beneficiados homologados entre } \\
01 / 01 / 1900 \text { e } 05 / 10 / 2007\end{array}$} \\
\hline SR 08 & São Paulo & 12.116 \\
\hline SR 07 & Rio de Janeiro & 4.525 \\
\hline SR 06 & Minas Gerais & 14.249 \\
\hline SR 20 & Espírito Santo & 3.833 \\
\hline \multicolumn{2}{|r|}{ Total } & 34.723 \\
\hline
\end{tabular}

SR30

Número de beneficiados homologados apenas nos anos de 2005 e 2006

\begin{tabular}{c|c}
\hline Homologações em 2005 & 18.000 \\
\hline Homologações em 2006 & 33.700 \\
\hline Total & 51.700 \\
\hline
\end{tabular}

Tabela 1: Comparativo de famílias assentadas por região.

Fonte: INCRA - Sipra: Diretoria de Obtenção de Terras e Implantação de Projetos de Assentamento - DT. Projetos de reforma agrária conforme fases de implementação, citado. Relação de beneficiários assentados no ano de 2005, citado.

Relação de beneficiários assentados no ano de 2006, citado.

O madeireiro "apadrinharia" o assentado e lhe daria tudo: emprego, infraestrutura, estradas, escola etc. Tudo na mais clássica reprodução de um mundo regido pelas relações de clientelismo e onde qualquer cidadania nunca foi apresentada como direito, mas como concessão e benevolência, em que as relações trilham a forma da dependência e do favor, "fazendo da violência simbólica a regra da vida social e cultural. Violência tanto maior porque invisível sob o paternalismo e o clientelismo, considerados naturais e, por vezes, exaltados como qualidades positivas do 'caráter nacional"' (CHAUÍ, 1996, p. 54).

Não é difícil entender a viabilidade da fusão do Estado e das madeireiras frente aos olhos dessa população. Uma sobreposição de personagens e papéis sintetizando um "provedor". Além do que, o poder patrimonial não se antagoniza como poder político ao Estado, ao contrário: "as oligarquias políticas no Brasil colocaram a seu serviço as instituições da moderna dominação política, submetendo a seu controle todo o aparelho de Estado" (MARTINS, 1994, p. 20). 


\section{A interdição dos assentamentos fantasmas}

Quando o esquema dos assentamentos de papel vem a público, em início de 2007, e enquanto o presidente do Incra e o ministro do MDA continuavam o "faz de conta" de que nada existia, um grande grupo de servidores recém-ingressados no Incra e lotados na SR30 reconhece o quadro de tramoias e se opõe a ele. À medida que foram tomando consciência das irregularidades em curso, assumiram por meio da sua entidade de representação, a Associação dos Servidores da Reforma Agrária (Assera), uma postura de obediência às normas de execução da reforma agrária e recusavam-se a cumprir ordens que as contrariassem. Não fosse a postura desses jovens servidores, haveria um quadro ainda mais grave e, provavelmente, em plena atividade.

A resistência posta por esses servidores - que, embora concursados, estavam todos em estágio probatório - foi um dos fatores que viabilizou a publicização da mais ampla gama de irregularidades. E, por conta disso, em 24 de agosto de 2007, a Justiça Federal atendeu liminarmente a um pedido do Ministério Público Federal (MPF) e interditou 99 assentamentos no oeste do Pará, que somam 30 mil km², área equivalente ao estado de Alagoas. Posteriormente, o número de assentamentos interditados chegou a 107.

Em 17 de setembro de 2007, o MPF tem atendido outro pedido de liminar e a Justiça Federal afasta do cargo cinco funcionários da SR30, entre eles o próprio superintendente, Pedro Aquino de Santana, "homem da reforma agrária" de Lula. Acusação: envolvimento em uma série de improbidades administrativas e formação de quadrilha.

Toda a tramoia era pública e evidente quando o Incra pareceu entrar em surto esquizofrênico: por um lado, o então presidente da autarquia, Rolf Hackbart, finge não haver nada de errado e declara em nota oficial divulgada no site do Incra: "É por acreditar na legitimidade dos trabalhos executados na região que continuaremos as ações planejadas e vamos recorrer da liminar expedida". Por outro, o próprio Hackbart reconhece o caótico estado de irregularidades ao alocar cerca de $\mathrm{R} \$ 3$ mi para se tentar sanear o absurdo cometido na SR30.

Em 22 de novembro de 2007, é suspensa a liminar que determinara o afastamento do superintendente e dos outros quatro servidores. O recurso assinado pelo Procurador Geral do Incra, Valdez Farias, afirma Aquino e os outros afastados como imprescindíveis para a consecução da reforma agrária na região e que seu afastamento atravancaria a "restauração da ordem pública, na medida em que promove a necessária regularização fundiária e apaziguaria os ânimos dos movimentos sociais".

Note-se, não se trata de uma defesa pessoal feita por advogado contratado, mas uma ação institucional, movida pelo próprio Incra por meio de sua Procuradoria. $\mathrm{Ou}$ seja, o órgão ratifica a conivência no processo de reforma agrária voltado ao madeireiro e com os maiores prejuízos aos povos da floresta, aos camponeses sem 
terra e ao meio ambiente.

Mas, de fato, Aquino e os outros afastados seriam vitais para certos assuntos. Vitais para conter os ânimos - não dos movimentos sociais que já se mobilizavam em protesto ao seu retorno -, mas dos madeireiros, que foram os primeiros a se levantarem aos berros quando o MPF obteve a interdição dos assentamentos. Aliás, a segunda manifestação veio da Secretaria do Estado de Meio Ambiente (SEMA) do estado do Pará, não em defesa do meio ambiente, como se poderia esperar, mas dos madeireiros, prejudicados pela impossibilidade de a Secretaria liberar planos de manejo nos assentamentos.

Aquino e os outros afastados foram responsáveis por uma situação de consequências incomensuráveis. Segundo a associação de servidores da SR30, hoje há milhares ou até dezenas de milhares de famílias homologadas às pressas, nos últimos dias de 2006, todas em assentamentos trocados. Algumas muito distantes da área que ocupam outras em locais que desrespeitariam seu modo de vida, como populações de terra firme homologadas em assentamentos de várzea e vice-versa. A formalização da troca de assentamento não é um trâmite simples e ninguém sabe onde encontrar esses "assentados" para que, ao menos, se inicie o processo, pois nada pode ser feito sem a assinatura das partes envolvidas.

Nas estradas vicinais da colonização da Transamazônica, ainda hoje é comum encontrar pessoas que dizem ter ficado sabendo que são "assentadas" em X ou Y assentamento, e que não têm ideia de onde fica tal lugar. Segundo os trâmites formais, esses "assentados" deveriam ser dados como desistentes, sem nunca mais poder acessar o programa de reforma agrária. E, repetindo, são milhares ou dezenas de milhares de famílias nessa situação.

A encenação de reforma agrária feita no Pará não assentou essas famílias e, pior, as privou da condição de candidatas a que, algum dia, pudessem ser atendidas em seu direito à terra e aos créditos da reforma agrária.

Aquino pouco tempo ficou, logo depois, após os holofotes se desviarem da questão, ele foi discretamente exonerado, sob a encenação de estar pedindo afastamento.

\section{As consequências da Ação Civil Pública (ACP) e o cancelamento dos assentamentos da SR30}

Após a interdição dos 107 assentamentos ${ }^{9}$, o Incra de Brasília assume

9 O MPF demandou o cancelamento de 99 assentamentos. Entretanto, a Justiça Federal decidiu suspender 107, incluindo oito assentamentos criados antes de 2005 , mas que estavam sobrepostos ou na área de influência direta de unidades de conservação. A interdição desses assentamentos anteriores a 2005 gera, ainda em 2016, um sério prejuízo às famílias assentadas e é um problema por ser resolvido.

Divididos por municípios, os assentamentos suspensos foram: Alenquer: 1. PDS Paraíso; 2. PA Miriti; 3. PA Porão; 4. PA Curumu; 5. PA Camburão II; 6. PA Camburão I; Altamira: 7. PA Esperança; 8. 
formalmente a questão. Assume o cargo de superintendente o diretor nacional do órgão, Raimundo Lima, o mesmo já citado neste texto e, desde o começo, como visto, envolvido com a proposta de se criar assentamentos para atender ao interesse de madeireiros.

Em setembro de 2007, o mês seguinte à interdição dos assentamentos, sob o acompanhamento de procuradores do Incra sediados em Brasília o órgão monta uma "força-tarefa", formada por servidores da SR30, com metas para ações de saneamento dos assentamentos interditados. No mês seguinte, outubro, o MPF e o Incra começam a esboçar os termos em que se daria a regularização da situação dos assentamentos interditados.

A força-tarefa era composta de servidores de diversas "correntes", inclusive, alguns técnicos que haviam se oposto ao esquema quando revelado. Raimundo Lima promete regularizar tudo em apenas três meses, mas sem produzir qualquer resultado sob sua coordenação, é afastado da "força tarefa" e, mais tarde, do próprio cargo de diretor do Incra.

Com o trabalho do grupo, alguns dos assentamentos interditados foram

PDS Mãe Menininha; 9. PDS Esperança; 10. PDS Brasília (abrange também Novo Progresso); Aveiro: 11. PDS São Manoel; 12. PA Urucurituba; 13. PA Daniel de Carvalho 1; 14. PDS Santa Rita; 15. PA Santa Cruz; 16. PA Brasília Legal; 17. PDS Santa Luzía; 18. PDS Nova Integração; 19. PDS Mário Braule Pinto da Silva; 20. PA Rio Cupari; 21. PAC Araipá-cupú (abrange também Rurópolis); 22. PDS Anjo da Guarda; Belterra: 23. PAC Bela Terra I; Curuá: 24. PDS Maloca; Faro: 25. PA Itaquera I; Itaituba: 26. PDS Cocalino; 27. PDS Novo Paraíso; 28. PDS Nova União; 29. PDS São João Batista; 30. PA Arixi; 31. PDS Novo Horizonte; 32. PDS Nova Brasília II; 33. PDS Nova Esperança; 34. PA Miritituba; 35. PA Ypiranga; 36. PAC Araxi; 37. PA São Benedito. Jacareacanga: 38. PDS Laranjal; Medicilândia: 39. PA Paraíso do Norte; 40. PDS Ademir Federicci; Monte Alegre: 41. PAC Cauçu B e Balança; 42. PAC Nova Altamira; 43. PA Muriçoca; 44. PA Vai Quem Quer; 45. PA Maripá; 46. PA Terra-preta e Olho D'água; 47. PA Baixão; 48. PA Cristo Rei; 49. PDS Serra-Azul; Novo Progresso: 50. PDS Terra Nossa; 51. PDS Nélson Oliveira; 52. PDS Jamanxim; Óbidos: 53. PA Repartimento; 54. PA Cipoal; 55. PA Vale do Açaí; 56. PA Curumu II; 57. PA Mamauru; 58. PA Acomec (abrange também Oriximiná); Oriximiná: 59. PAC Itapecurú; 60. PAC Ananizal; 61. PAC Monte Muriá; 62. PAC Acomtags; 63. PAC Iripixi; Pacajá: 64. PA Anapuzinho (abrange também Anapu); 65. PDS Liberdade; 66. PA Cupuzal; 67. PA Renascer; 68. PA Terra para a Paz (abrange também Portel); Placas: 69. PDS Água Preta; 70. PDS Castanheira; 71. PA Macanã II; 72. PDS Avelino Ribeiro; 73. PDS Arthur Faleiro; 74. PA Macanã; Portel: 75. PDS Liberdade I; 76. PDS Horizonte Novo (abrange também Porto de Moz); Prainha: 77. PDS Vila Nova I; 78. PDS Vila Nova II; 79. PA Curuá; Rurópolis: 80. PDS Milho Verde; 81. PA Paraíso; 82. PDS Cupari; 83. PDS Divinópolis; 84. PDS Novo Mundo; 85. PA Campo Verde; Santarém: 86. PDS Renascer II; 87. PAC Bela Terra II; 88. PAC Bom Sossego; Senador José Porfírio: 89. PDS Itatá; Terra Santa: 90. PA Jamary; 91. PA Vira Volta; 92. PDS Esperança do Trairão; 93. PA Rio Cigano; Trairão: 94. PDS Água Azul, 95. PA Nossa Senhora de Fátima; 96. PDS Pimental; 97. PDS Taboari; 98. PDS Boa vista do Caracol (abrange também Ruropólis); 99. PA Areia; 100. PA Rio Bonito; Uruará: 101. PAC Nova União; 102. PDS Irmã Dorothy; 103. PDS Santa Clara; 104. PAC Ouro Branco I; 105. PAC São Sebastião do Tutui; 106. PAC Ouro Branco II; 107. PDS Ouro Branco. 
cancelados pelo próprio Incra, que, sob critérios técnicos, ou melhor, sob critérios técnicos direcionados para avaliar a área como um assentamento de reforma agrária (e não como um estoque de madeira), constatou a completa inadequação. Por meio da nota abaixo, em agosto de 2009, a assessoria de comunicação da SR30 justificou o ato:

O Diário Oficial da União (DOU) publicou, no dia 3 de agosto deste ano, a Portaria $\mathrm{n}^{\circ} 19$, de 23 de julho de 2009, na qual consta a revogação das portarias de criação dos Projetos de Desenvolvimento Sustentável (PDS) Santa Rita, Santa Luzia e Anjo da Guarda, localizados no Município de Aveiro.

A decisão foi tomada pelo Comitê de Decisão Regional desta Superintendência, com base em relatório técnico elaborado por força-tarefa instituída no Incra. Esta analisa os processos de criação de assentamentos interditados pela Justiça Federal, situação em que se encontravam os PDS's Santa Rita, Santa Luzia e Anjo da Guarda.

Dentre os motivos elencados que culminaram na avaliação de inviabilidade técnica e ambiental dos PDS's citados nesta nota, estão a distância dos projetos em relação à área urbana de Itaituba e Aveiro; a dificuldade de acesso; a existência de número reduzido de famílias com morada habitual ou permanente; e a incidência sobre o entorno de unidades de conservação.

As famílias cadastradas nesses PDS's retornarão à condição de candidatas a clientes de reforma agrária, cabendo ao Incra avaliar, posteriormente, o perfil de cada uma delas e a possibilidade de assentá-las em outros locais (Disponível em: <candidoneto.blogspot.com/2009/08/justificando.html>. Acesso em: abr. 2010).

Mais tarde, outros nove assentamentos seriam também cancelados pelo próprio Incra por sobreposições a unidades de conservação, terras indígenas, territórios quilombolas ou por simples inviabilidade técnica. E, no total, o número de portarias de criação de projetos de assentamentos interditados que foram revogados pelo Incra chegou a 25.

Outros assentamentos, entretanto, eram projetos que, apesar da caótica irregularidade, atendiam a interesses dos beneficiários da reforma agrária - e não interesses de madeireiros - e tiveram (mal ou bem, de forma razoável ou não) seus processos saneados. Em função disso, quase dois anos depois da interdição, no início de 2009, a Justiça Federal em Santarém liberou os primeiros sete assentamentos.

Em março de 2010, são liberados pela Justiça Federal outros treze assentamentos que, até então, estavam interditados e foram regularizados. Até aí, nada além do razoável, pois era acordado entre o Incra e o MPF que os assentamentos que 
tivessem os vícios sanados e não fossem aqueles voltados a madeireiros, deveriam ser desinterditados. Nesse momento, entretanto, a decisão judicial trouxe uma preocupante brecha à grilagem: determinou que fossem excluídas dos assentamentos desinterditados as "posses", para que fossem regularizadas e tituladas pelo Programa Terra Legal ${ }^{10}$. Tais "posses", muitas vezes, nada mais eram do que detenções ilegais de terras públicas que se valiam de tentativas de regularização fundiária por meio do uso de laranjas.

Sobre a decisão, vale reproduzir a interessante análise do servidor do Incra Cândido Cunho, publicada imediatamente na sequência do ato:

Mas, a decisão extrapolou o pedido e determinou que o Incra examine, nos 13 assentamentos liberados, as posses que estão passíveis de serem excluídas e, posteriormente, tituladas pelo programa de regularização fundiária na Amazônia Legal, o "Terra Legal", criado a partir da MP 458 convertida na Lei 11.952/2009. Ou seja, pela decisão judicial parte das áreas será destinada não mais com parte da área viabilizada e licenciada como projetos de assentamentos, mas como áreas de "regularização fundiária".

Agora vêm as questões: se o laudo, mapas, licença ambiental, capacidade do assentamento, área de reserva legal e uso econômico são definidos a partir de um perímetro e uma área específica, como assegurar a viabilidade de um assentamento que terá áreas excluídas para "regularização fundiária"? E mais: como o Incra vai atuar com políticas de desenvolvimento (estradas, poços, casas) em áreas que poderão ser excluídas do projeto? Resposta: a farra da grilagem explica... (CUNHA, 2010).

Mas a surpresa maior estava por vir em abril de 2011, pela mão do juiz Francisco de Assis Garcês Castro Júnior, da Subseção de Santarém, no julgamento do mérito da ACP movida inicialmente contra o Incra e o Estado do Pará por meio da Secretaria de Ciência e Tecnologia (Sectam, atualmente, SEMAS - Secretaria de Meio Ambiente e Sustentabilidade). Garcês era o mesmo juiz que havia interditado os tais "assentamentos de papel". Entretanto, após isso, houve, entre o Incra e o MPF, acordo que permitia a liberação judicial dos projetos à medida que fossem saneadas as irregularidades apontadas nos atos de criação de parte dos projetos e o cancelamento de outros, especialmente aqueles sobrepostos a unidades de conservação, terras indígenas e sem viabilidade técnica, social e econômica (CUNHA, 2011).

A sentença de Garcês contrariou, inclusive, várias decisões anteriores que haviam

\footnotetext{
${ }^{10}$ O Programa Terra Legal, implementado pelo MDA, objetiva a regularização fundiária de ocupações em terras públicas federais situadas na Amazônia Legal, a partir da Lei n 11.952 de 2009. Para uma visão crítica do Programa, que teria potencializado a legitimação da grilagem de terras públicas, veja-se Cunha, Torres e Guerreiro (2011).
} 
entendido por bem liberar assentamentos que estivessem saneados em seus vícios de origem e atendessem ao público a quem, de fato, eram vocacionados.

Se o cancelamento, em meados de 2007, dos 106 assentamentos seria uma medida razoável contra a gigantesca farsa armada pelo conluio Incra-madeireiros ${ }^{11}$, em 2011 a situação era bem distinta. E não só por conta dos vários assentamentos que haviam sido regularizados e já liberados.

Se, em 2007, cancelar os assentamentos era uma forma de evitar que os madeireiros controlassem uma porção de terras do tamanho do estado de Alagoas; em 2011, o cancelamento significava disponibilizar a porção de terras do tamanho do estado de Alagoas para grileiros, então municiados pelo Programa Terra Legal como nova e eficiente ferramenta de grilagem de terras públicas (CUNHA, TORRES \& GUERREIRO, 2011).

Em outras palavras, parece que o governo- ao menos na região oeste do Pará encontrou sempre uma opção pior aos camponeses e mais favorável à grilagem e às madeireiras. Se, em 2007 os assentamentos de papel eram algo muito ruim, em 2011 havia uma opção potencialmente ainda pior, a legitimação da grilagem via Programa Terra Legal ${ }^{12}$.

Quatro meses após a sentença de Garcês, em resposta a instrumento impetrado pela Advocacia Geral da União, o Tribunal Regional da $1^{\mathrm{a}}$ Região suspendeu parcialmente a execução da sentença proferida por Garcês, de modo que foram excluídos do cancelamento os assentamentos já regularizados e anteriormente cancelados ${ }^{13}$.

Até hoje a situação de irregularidade por conta da criação dos assentamentos fantasmas persiste em prejuízo de camponeses sem terra, assentados e, sobretudo, da reforma agrária. Se houve o desmonte do esquema Incra-madeireiros, as terras onde os madeireiros demandavam os assentamentos não foram retomadas pelo Incra e destinadas a fim coerente, de modo que permaneceram em poder desses grupos criminosos que ainda hoje as saqueiam.

\footnotetext{
11 A nosso entender, mesmo entre os 99, alguns assentamentos não deveriam ter sido arrolados no processo, em especial os criados antes de 2005. Se o foram, é porque, sem tempo e condições para se verificar in loco todos os projetos, o MPF acabou por se apegar às irregularidades nos procedimentos de criação.

${ }^{12}$ Sobre a ação do Programa Terra Legal em prol da grilagem, veja-se Cunha, Torres e Guerreiro (2011) e Tribunal de Contas da União (2014).

${ }^{13}$ Os projetos liberados foram: RESEX (Reserva Extrativista) Verde para Sempre (Unidade de Conservação) - Porto de Moz; PA Vai Quem Quer - Monte Alegre; PA Rio Cupari - Aveiro; PA Paraíso - Rurópolis; PA Ypiranga - Itaituba; PA São Benedito - Itaituba; PA Areia - Trairão; PAE Curuá II - Prainha; PAC Itapecuru - Oriximiná; PA Campo Verde - Rurópolis; PA Curumu Alenquer; PA Esperança - Altamira; PA Terra para Paz - Pacajá; PDS Mãe Menininha - Altamira; PA Nossa Senhora de Fátima - Trairão; PA Renascer - Pacajá; PA Cristo Rei - Monte Alegre; PA Baixão - Monte Alegre; PDS Serra Azul - Monte Alegre; PDS Terra Nossa - Altamira; PDS Brasília Altamira; PDS Paraíso - Alenquer; PA Brasília Legal - Aveiro; PA Rio Bonito - Trairão.
} 


\section{Considerações Finais}

Quase quatro décadas após a prometida "reforma agrária da paz" dos militares, poupando os latifúndios e removendo camponeses sem terra - e inquietações sociais do Sul e do Nordeste para a Amazônia (IANNI, 1979; MARTINS, 1984; OLIVEIRA, 2005), a distribuição de terras públicas na Amazônia continuou a alimentar o processo de reforma agrária.

Pretendeu-se, aqui, demonstrar o enredo em que Estado e grupos econômicos arquitetaram e manipularam políticas territoriais para viabilizar e revestir de legalidade o saqueio das florestas públicas na região oeste do Pará. E, a reboque desse processo, fabricar-se vultoso e irreal número de famílias assentadas.

No oeste paraense estariam mais de 50 mil das supostas 381 mil famílias assentadas, entretanto, o número propagandeado pelo governo não correspondia à realidade, uma vez que muitos dos "assentamentos" só existiam no papel. Assim, o simulacro de reforma agrária feito no Pará em 2005 e 2006 não assentou as famílias anunciadas e ainda dificultou a chance de que, algum dia, pudessem ser atendidas em seu direito à terra e aos créditos da reforma agrária, uma vez que, enquanto não corrigida a situação, tais famílias já constarão como assentadas nos cadastros do Incra.

Com a criação fictícia de assentamentos, colateralmente à fabricação de números e à apropriação ilegítima dos recursos florestais por madeireiros, fazia-se, enfim, uma "reforma agrária" a saciar o mercado ilegal da madeira, e que ignorava a incompatibilidade desses com os interesses de camponeses sem terra. Para os primeiros, era necessário que os assentamentos fossem implantados em áreas com estoques ainda intocados de madeiras nobres, ou seja, nas distantes florestas primárias ainda não saqueadas. Porém, justamente essa condição tornava diminuta a possibilidade de famílias camponesas se instalarem no local.

A direção nacional do Incra jamais assumiu publicamente o esquema dos assentamentos fictícios voltados para madeireiras. Localmente, o Incra optou por banalizar o feito. O esquema chegou a ser alegado como uma espécie de "parceria" com as madeireiras, como se sua instalação fosse meio de viabilizar o assentamento. Tudo bem ao gosto de uma orientação neoliberal que oblitera os efeitos das relações de dependência engendradas e apregoa, como único caminho, o pacto com os grandes empreendimentos, sejam madeireiros, hidrelétricos, minerais etc.

Passados nove anos da obstrução do processo, ocorrida com a interdição judicial de mais de uma centena de assentamentos em consequência da ACP impetrada pelo MPF, muito pouco houve de repercussão sobre o caso. Quase nada houve de consequência sobre a farsa da reforma agrária os sobre os interesses eleitorais do PT no Pará e as campanhas financiadas pelas madeireiras. Sem prejuízo de toda a tramoia criada, olhando de hoje, talvez o que mais chame a atenção não seja a pretensão de solapar a terra e a floresta sob o rótulo (e em detrimento) da reforma agrária, mas, antes, o silêncio dos movimentos sociais diante disso.

Os fictícios números de beneficiados de assentamentos fantasmas da SR30, 
considerados pelo II PNRA, jamais foram revisados e seguem computados como se integrassem a "maior reforma agrária da história brasileira".

É quase como se nada tivesse existido.

\section{Agradecimento}

Registro um especial agradecimento ao engenheiro agrônomo e perito federal agrário Cândido Neto da Cunha pelos comentários integralmente incorporados a este texto.

\section{Bibliografia}

ALMEIDA, Alfredo Wagner B. (1988) O trabalho escravo como instrumento de escravidão. Revista Humanidades, Brasília, UnB, ano V, nº 17.

BRASIL. (2005) CPI da Biopirataria, no 1136/05. Brasília, 11 ago. Disponível em <http://www.camara.gov.br/internet/comissao/index/cpi/pirataria_nt110805.htm>. Acessado em: out. 2006.

CHAUÍ, Marilena. (1996) Conformismo e resistência: aspectos da cultura popular no Brasil. 1. ed., 6. reimp. São Paulo: Brasiliense.

COHENCA, Daniel. (2010) Nota de esclarecimento: inocentado das acusações, Daniel Cohenca mostra o real motivador de sua exoneração da Gerência do Ibama de Santarém“. Disponível em: <http://candidoneto.blogspot.com/2010/01/pratoslimpos.html>. Acessado em: mar. 2010.

CUNHA, Candido Neto da. (2010) Farra da grilagem: juiz "desinterdita" assentamentos e libera áreas para "Terra Legal". 30 mar. Disponível em: <http://candidoneto.blogspot.com.br/2010/03/farra-da-grilagem-juizdesinterdita.html >. Acessado em: jan. 2012.

(2011) Justiça Federal determina o cancelamento de mais de 100 assentamentos no Oeste do Pará: decisão do mérito no caso dos "assentamentos de papel" contradiz liminar anterior. 17 abr. 2011. Disponível em: <http://candidoneto.blogspot.com.br/2011/04/bomba-justica-federal-determinao.html>. Acessado em: abr. 2011.

; TORRES, Mauricio \& GUERREIRO, Natalia Ribas. (2011) Ri melhor quem grila por último: a MP 458 e as últimas artimanhas da grilagem na Amazônia. In: Anais do V Simpósio Internacional de Geografia Agrária e VI Simpósio Nacional de Geografia Agrária, Belém, PA.

PAJU - NATUREZA VIVA E PRESERVADA. (2010) Daniel Cohenca, ex-gerente do Ibama de Santarém, diz que PT usou órgão para vencer eleições municipais no Oeste do Pará. Disponível em: <http://www.paju.net.br/velhos-novos-verdes/danielcohenca-ex-superintendente-do-ibama-de-santarem-diz-que-pt-usou-orgao-paravencer-eleicoes-municipais-no-oeste-do-para/> . Acessado em: fev. 2010. 
GREENPEACE. (2007) Assentamentos de papel, madeira de lei. Relatório Denúncia. Manaus: Greenpeace, ago. Disponível em: http://www.observatoriodoagronegocio.com.br/page41/files/gpbr0708amrelassincrapt v2 .pdf. Acessado em: out. 2009.

GUERREIRO, Natalia. (2007) Fraudes no Incra do Pará. Carta Capital, 31 out. São Paulo.

IANNI, Octávio. (1979) Colonização e contra-reforma agrária na Amazônia. Petrópolis: Vozes.

INSTITUTO NACIONAL DE COLONIZAÇÃO E REFORMA AGRÁRIA (INCRA). (2007) Plano de ação superintendência regional de Santarém. Brasília, jun.

. Portaria $\mathrm{n}^{\mathrm{o}} 88$, de outubro de.1999.

Portaria n ${ }^{\circ} 477$, de novembro 1999.

JORNAL DE SANTARÉM E BAIXO AMAZONAS. (2005) Empresários tiveram várias reuniões com o Incra. Santarém, 9 a 15 de dezembro.

LEAL, Paulo L. (2005) PDS 'na marra': empresários desmentem superintendente. Jornal de Santarém e Baixo Amazonas, Santarém, 3 a 9 de dezembro. p. 7.

MARTINS, José de Souza (1984) A militarização da questão agrária do Brasil. Petrópolis: Vozes.

. (1994) O poder do atraso. São Paulo: Hucitec.

MINISTÉRIO DO DESENVOLVIMENTO AGRÁRIO; INSTITUTO NACIONAL DE COLONIZAÇÃO E REFORMA AGRÁRIA. (2004) Portaria Conjunta $n^{\circ} 10$, de 10 de dezembro de 2004. Brasília.

MINISTÉRIO PÚBLICO FEDERAL. Procuradoria de Santarém. ICP $\mathrm{n}^{\circ}$ 1.23.002.000185/2007-76/PRM/STM/MPF.

MORENO, Gislaine. (1993) Os (des)caminhos da apropriação capitalista da terra em Mato Grosso. Tese (Doutorado em Geografia Humana) - Faculdade de Filosofia, Letras e Ciências Humanas, Universidade de São Paulo. São Paulo.

OLIVEIRA, Ariovaldo Umbelino de. (1997) A fronteira amazônica mato-grossense: grilagem, corrupção e violência. Tese (Livre-docência em Geografia) - Faculdade de Filosofia, Letras e Ciências Humanas, Universidade de São Paulo. São Paulo.

(2005) BR-163 Cuiabá-Santarém: geopolítica, grilagem violência e mundialização. In: TORRES, Maurício (Org.). Amazônia Revelada: os descaminhos ao longo da BR-163. Brasília: CNPq/DNIT. pp. 67-183.

ROCHA, Jan. (2005) Trabalho escravo: presente, passado e futuro. In: TORRES, M. (Org.). Amazônia Revelada: os descaminhos ao longo da BR-163. São Paulo: CNPq. SOUZA, Oswaldo Braga de. (2005) Governo Lula acaba se complicando no conflito de Novo Progresso (PA). Isa, 15 fev. Disponível em: <http://209.85.207.104/search?q=cache:klsP_h8IPHMJ:https://www.socioambiental .org/nsa/detalhe $\% 3$ Fid\%3D1920+\%C3\%B4nibus+\%22novo+progresso $\% 22+\% 22 \mathrm{pl}$ anos + de + manejo $\% 22+$ tasso $\&$ hl $=$ pt-BR\&ct $=\mathrm{clnk} \& \mathrm{~cd}=1 \& \mathrm{gl}=\mathrm{br}>$. Acessado em: dez . 2007. 
TRIBUNAL DE CONTAS DA UNIÃO; SECRETARIA GERAL DE CONTROLE EXTERNO; SECRETARIA DE CONTROLE EXTERNO DO AMAZONAS. (2014) Relatório se auditoria de conformidade no Programa Terra Legal Amazônia. TC 015.859/2014-2. Fiscalização 402/2014. Brasília. Disponível em https://pt.scribd.com/doc/252651209/Relatorio-de-Fiscalizacao-TCU-do-ProgramaTerrra-Legal. Acessado em: jan. 2015.

TORRES, Mauricio. (2012) Terra privada, vida devoluta: ordenamento fundiário e destinação de terras públicas no oeste do Pará. Tese (Doutorado em Geografia Humana) - Faculdade de Filosofia, Letras e Ciências Humanas, Universidade de São Paulo. São Paulo. . (Mimeo). (s.d.) Soja, substantivo masculino: inventário crítico da grilagem no planalto santareno. . (2005) Fronteira, um eco sem fim. In: (Org.). Amazônia Revelada. Brasília: CNPq. . (2007a) Governo ajuda madeireiras a devastar a Amazônia. Caros Amigos, ano XI, nº 128, nov. São Paulo: Ed. Casa Amarela.

. (2007b) A reforma agrária que virou plano de manejo. O Liberal, 05 dez. Belém. p. 2.

. (2008) O discurso ecotecnocrata. Página 22, nº 17, mar. São Paulo: FGV. pp. 54-57.

Data de submissão: 09/12/2015.

Data de aceite: 06/07/2016. 